Gadjah Mada International Journal of Business

May 2002, Vol. 4, No. 2, pp. 227-236

\title{
RE-EXAMINING THE EXISTENCE OF LOW PRICE-EARNINGS RATIO EFFECTS: A Descriptive Approach to the Case of Indonesian Stock Market
}

\author{
Marwan Asri Sw.
}

From practical point of view, Price-Earnings $(P / E)$ ratio is one of numerous important aspects to consider. Analysts, investors, and traders in stock markets use P/E ratio-together with other information- in analyzing the past performance, and predicting the future prospect of securities in the market. However, noting its importance, there are some significant disagreements among researchers regarding the ability of $P / E$ ratio in providing "correct information" about the future return of company stocks. One of the topics under discussion is about the presence of so-called low P/E effect, which hypothesizes that high P/E will be followed by low returns and low P/E will be followed by high returns.

This study, by repeating partially Johnson et al. (1989) procedures, was trying to confirm the low $\mathrm{P} / \mathrm{E}$ effect hypothesis in Indonesian market. The study involved 267 stocks listed in Jakarta Stock Exchange in the sample frame and selected the period of 1994-2000 as the focus of analysis. The study also has an intention to investigate whether there was a structural change in return-P/E relationship from the pre-crisis period (1994-1996) to the crisis period (1998-2000).

The procedure of analysis was divided into two sections. In the first section a descriptive macro (market) analysis was presented, to test the hypothesis at the market level. It started with an overview about the fluctuation and trend of market P/E ratios during the period of 1991-2000, and followed by investigating the relationship between market $P / E$ and the following returns. A regression analysis was also performed to strengthen the analysis from statistical point of view. In the second section, analysis is more directed to the portfolio level where the portfolios were ranked according to their P/E ratios. The study was concluded with a main finding that does not support the low P/E effect hypothesis.

Keywords: low p/e effect; price-earning ratio 
The ability of price-earnings (P/E) ratios in reflecting the benefits gained by investors have been explored, analyzed and discussed by many researchers as well as practitioners since decades ago. Among several questions addressed, the simplest —and the most important—one is whether the high $\mathrm{P} / \mathrm{E}$ stocks provide high returns to the investors and vice versa. Yet, until nowadays, the common agreement has not been reached. Some analysts believe that high $\mathrm{P} / \mathrm{E}$ ratio in the past is usually followed by slow growth in stock prices. This is one of the reasons why many investors pay great attention to the high $\mathrm{P} / \mathrm{E}$ ratios in the U.S. stock market in mid to late nineties. However, the other group of analysts disagree and argue that history is no longer a true guide because fundamental changes in the economy have made stocks more attractive to investors. In other words, they justify a high P/E ratio (Shen 2000).

$\mathrm{P} / \mathrm{E}$ ratio itself can be interpreted in many ways. Cragg and Malkiel (1982), and Litzenberger and Rao (1971), for instance, viewed P/E ratio as an indicator of earning growth. While, Ball (1978) interpreted $\mathrm{P} / \mathrm{E}$ ratio as a measure of risk. Further, Boatsman and Baskin (1981), and Alford (1992) supported the interpretation given by Graham et al. (1962), mentioning that $\mathrm{P} / \mathrm{E}$ ratio is a measure of earnings capitalization rate. This study, in essence, follows the definition of Basu (1977) and Jaffee et al. (1989), in which P/E ratio is defined as the indicator of stock misspricing.

In a study performed more than twenty years ago, Basu related the stocks' performance to their $\mathrm{P} / \mathrm{E}$ ratios in his effort to test the efficient market hypothesis. His findings confirmed that returns provided by low $\mathrm{P} / \mathrm{E}$ stocks were significantly higher than those of high $\mathrm{P} / \mathrm{E}$ common stocks. These findings were then supported by a number of researchers around the time of Basu's research, such as Roll (1981), Banz (1981), Brown et al. (1983), Keim (1983), Reinganum (1983), Francis (1986), and Radcliff (1987). The phenomenon is then commonly known as "low P/E effect" (Klein and Rosenfeld 1991), even though it is not clear whether this effect is homogeneous across all stocks with low $\mathrm{P} / \mathrm{E}$ or whether it can be addressed to a particular group of stocks.

On the other side, some other researchers have challenged the argument of "low P/E effect." Jones (1987) and Johnson et al. (1989) are among those who find the opposite results in their studies. Jones found that stocks with low P/E ratio produced significantly lower risk adjusted rates of return as compared to those following the Standard and Poor 500 or other investment strategies. Similarly, Johnson et al. (1989) found that low $\mathrm{P} / \mathrm{E}$ ratio portfolios earned the lowest average monthly rates of return - even lower than the monthly risk-free rate.

Given the conflicting findings of those researchers, the main purpose of this study, in general, is to re-examine the ability of $\mathrm{P} /$ $\mathrm{E}$ ratio to explain the stock performance, as measured by stock return. In a more specific term, the study is intended to answer whether the "low P/E effect" is found in Indonesian stock market. It is also expected to show further the behavior of investors in an emerging market, where some fraction of the market players are not sophisticated. The study hypothesizes that the low P/E effect is found in Indonesian stock market.

The steps and procedures employed by Johnson et al. (1989) — who followed Basu's procedures - are partially applied in the study. Johnson et al. (1989) investigated the relationship between the investment performance of stocks and their P/E 
ratios. They analyzed portfolio returns, risks, as well as performance indices after grouping the portfolio according to their $\mathrm{P} / \mathrm{E}$ ratios.

\section{Research Methodology}

Analysis of the presence of low $\mathrm{P} / \mathrm{E}$ effect is divided into two sections. The first part consists of a market analysis, which is a more macro scenario. Here we investigate the historical records of average market's $\mathrm{P} / \mathrm{E}$ ratios, where the data are collected from the Jakarta Stock Exchange (JSX) monthly statistics, over the period of 1991-2000. For the purpose of the study, we calculate average market $\mathrm{P} / \mathrm{E}$ ratios for every three months by using the following formula:

$$
\operatorname{Av}(\mathrm{P} / \mathrm{E})=\sum_{\mathrm{t}=1}^{3}(\mathrm{P} / \mathrm{E})_{\mathrm{t}} / 3 \ldots \ldots \ldots(\mathrm{Eq} .1)
$$

where:

$(\mathrm{P} / \mathrm{E})_{\mathrm{t}}=$ Market $\mathrm{P} / \mathrm{E}$ at month $t$

The "behavior" of average market's $\mathrm{P} / \mathrm{E}$ is presented in Figure 1. In order to provide some explanations about the occurrence of low P/E effect in the market, we calculate average market returns for the three-month period following the recorded P/E. For instance, we calculate average market returns for April through June 1995 in order to detect whether they have any particular patterns following the January-March 1995 average P/E ratio. The results of the calculation procedure are presented in Table 1.

To provide supporting information we construct Figure 2, which consists of dots representing average market returns following the average $\mathrm{P} / \mathrm{E}$ ratios. We also perform a regression analysis between the market average return following recorded $\mathrm{P} / \mathrm{E}$ (as a dependent variable) and average market $\mathrm{P} / \mathrm{E}$ ratio (as the independent variable). This analysis is expected to

Figure 1. Average P/E Ratios of the Jakarta Stock Exchange, 1991-2000

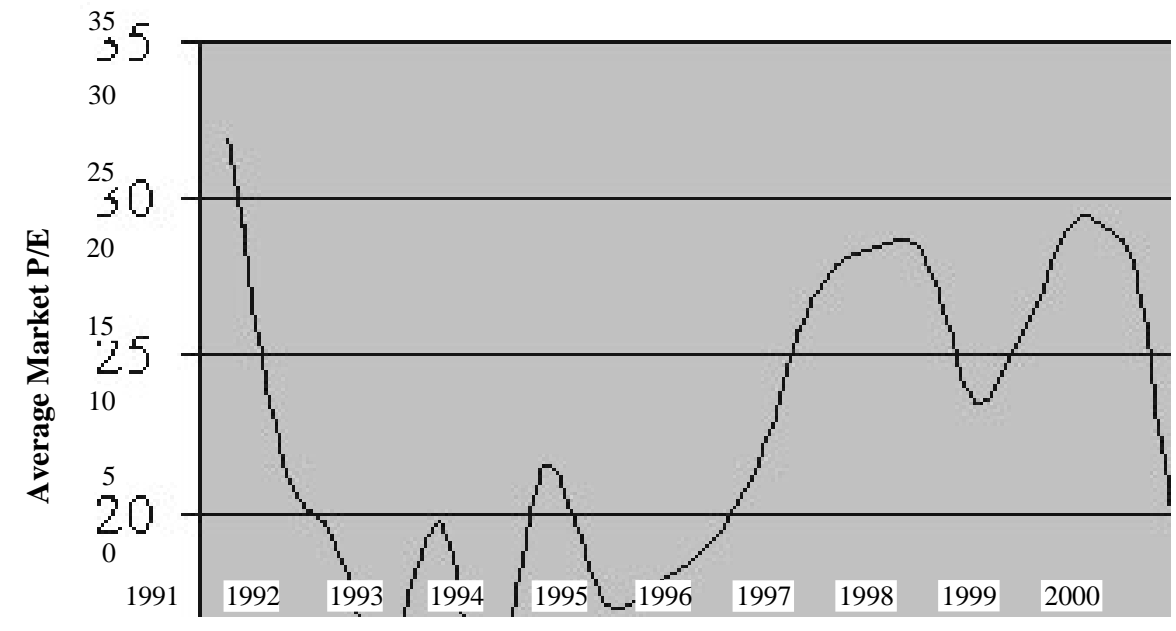

Time 
GadjahMadaInternationalJournal ofBusiness,May2002, Vol.4,No.2

Table 1. Average Market P/E Ratios and Average Market Returns

\begin{tabular}{|c|c|c|c|c|c|}
\hline Year & P/E Ratio & Return (\%) & Year & P/E Ratio & Return (\%) \\
\hline 1991a & 21.90 & -2.42 & $1996 a$ & 22.50 & 4.61 \\
\hline $1991 b$ & 21.85 & -0.71 & $1996 \mathrm{~b}$ & 17.25 & 0.58 \\
\hline $1991 c$ & 19.13 & -8.13 & $1996 c$ & 16.47 & -0.94 \\
\hline 1991d & 15.48 & -0.56 & $1996 d$ & 18.32 & 3.62 \\
\hline $1992 a$ & 9.82 & 2.03 & $1997 \mathrm{a}$ & 19.13 & 1.46 \\
\hline $1992 b$ & 13.90 & 2.91 & $1997 b$ & 21.91 & 3.10 \\
\hline $1992 \mathrm{c}$ & 21.51 & -3.40 & $1997 \mathrm{c}$ & 17.43 & -7.09 \\
\hline $1992 d$ & 17.29 & -3.10 & $1997 d$ & 12.12 & -9.40 \\
\hline $1993 a$ & 17.86 & 1.51 & $1998 \mathrm{a}$ & 13.38 & 10.82 \\
\hline $1993 b$ & 18.97 & 3.03 & $1998 b$ & 13.48 & -5.86 \\
\hline $1993 c$ & 21.77 & 4.87 & $1998 \mathrm{c}$ & 4.55 & -13.41 \\
\hline $1993 d$ & 26.78 & 8.71 & $1998 d$ & 3.75 & 13.46 \\
\hline $1994 a$ & 28.42 & -4.27 & 1999a & 3.21 & -0.39 \\
\hline $1994 b$ & 28.38 & -3.71 & $1999 b$ & 4.10 & 19.13 \\
\hline $1994 c$ & 23.48 & -1.12 & $1999 \mathrm{c}$ & 4.60 & -6.08 \\
\hline $1994 d$ & 26.17 & -2.37 & $1999 d$ & 9.19 & 7.55 \\
\hline $1995 \mathrm{a}$ & 29.42 & -2.86 & $2000 a$ & 13.68 & -4.74 \\
\hline $1995 b$ & 28.01 & 4.95 & $2000 b$ & 14.38 & -3.35 \\
\hline $1995 c$ & 18.46 & 0.10 & $2000 \mathrm{c}$ & 6.08 & -6.45 \\
\hline $1995 d$ & 22.06 & 1.44 & $2000 d$ & 5.11 & -0.30 \\
\hline
\end{tabular}

a Average of $1^{\text {st }}$ Quarter : January-March

${ }^{\mathrm{b}}$ Average of $2^{\text {nd }}$ Quarter : April-June

${ }^{c}$ Average of $3^{\text {rd }}$ Quarter : July-September

${ }^{\mathrm{d}}$ Average of $4^{\text {th }}$ Quarter : October-December

strengthen our conclusion about the market reaction to $\mathrm{P} / \mathrm{E}$ ratios.

The second part of analysis includes a more micro (portfolio) level. The study involves 267 stocks in the Jakarta Stock Exchange (JSX), without any intention to focus on some specific industries. Using 1997 as a "shifting year", namely the year when economic crisis started to hit capital market performance, the data are grouped into two three-year periods: Period I, namely the "pre-crisis period" (1994-1996) and Period II, the "crisis period" (19982000). Each of the periods is analyzed separately under hypothesis that some structural changes in investor behavior are detected.

As a starting point, we array all stocks in the data set according to their $\mathrm{P} / \mathrm{E}$ ratios for the year. P/E ratios are calculated by using the following formula:

$$
\mathrm{P} / \mathrm{E}_{\mathrm{i}, \mathrm{t}}=\mathrm{PDec}_{\mathrm{i}, \mathrm{t}} / \mathrm{EPS}_{\mathrm{i}, \mathrm{t}} \ldots \ldots \ldots \ldots \text { (Eq. 2) }
$$

where:

$\mathrm{P} / \mathrm{E}_{\mathrm{i}, \mathrm{t}}=$ Price-earnings ratio of company $i$ at year $t$ 
Figure 2. Average Market Return vs. Market P/E Ratio

25

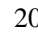

15

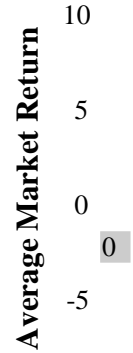

5
10

15

20
25

30
35

\section{Average Market P/E Ratio}

$\mathrm{PDec}_{\mathrm{i}, \mathrm{t}}=$ December closing price of company stock $i$ at year $t$

EPS $_{\mathrm{i}, \mathrm{t}}=$ earnings per share of stock $i$ at year $t$

After calculating the $\mathrm{P} / \mathrm{E}$ ratios for all stocks, then we rank them from the lowest to the highest $\mathrm{P} / \mathrm{E}$. The highest $\mathrm{P} / \mathrm{E}$ group might consist of stocks with negative earnings. Then, following (partly) Johnson et al. (1989), we form three equal-sized portfolios, starting from the lowest $\mathrm{P} / \mathrm{E}$ portfolio. Thus, the third portfolio includes the companies with negative earnings. For more detail analysis, we construct another two portfolios. The fourth portfolio consists of high $\mathrm{P} / \mathrm{E}$ stocks, excluding the regative earning companies. The last portfolio is the market perfolio. The performance of market portfolio is needed in the analysis for comparison purposes.

After constructing four portfolios, we chloulate the January-to-January monthly returns for every stock for period I and for period II, respectively ${ }^{1}$. With an assumption of equal allocation weight for each sto $6 \mathrm{k}$ then we calculated the portfolio rates of return. This procedure is repeated for every year, from 1994 to 1996 for period I,

${ }^{1}$ In his study, Basu (1977) calculated the monthly rates of refurn from April to April, with an argument that investors do not have access to company's financial stafementand exaetearnings figures-at the-end-of December. However, Ball and Brown (1968) have shown that the market reacts as though it possesses such information (Johnson et al. 1989). Thus, following Johnson et al. 1989, we calculated the monthly returns from January to January. 
GadjahMadaInternationalJournal ofBusiness,May2002, Vol.4,No.2

Table 2. Portfolio Returns, Standard Deviation, and Beta

\begin{tabular}{|c|c|c|c|c|c|c|}
\hline \multirow[b]{2}{*}{ Portfolio* } & \multicolumn{2}{|c|}{ Returns } & \multicolumn{2}{|c|}{ Standard Dev. $(\sigma)$} & \multicolumn{2}{|c|}{ Beta $(\beta)$} \\
\hline & $\begin{array}{c}\text { Period I } \\
(1994- \\
\text { 1996) }\end{array}$ & $\begin{array}{c}\text { Period II } \\
\text { (1998- } \\
\text { 2000) }\end{array}$ & $\begin{array}{c}\text { Period I } \\
(1994- \\
\text { 1996) }\end{array}$ & $\begin{array}{c}\text { Period II } \\
(1998- \\
2000)\end{array}$ & $\begin{array}{c}\text { Period I } \\
(1994- \\
\text { 1996) }\end{array}$ & $\begin{array}{c}\text { Period II } \\
(1998- \\
\text { 2000) }\end{array}$ \\
\hline 1 & 0.016 & 0.064 & 0.007 & 0.021 & 0.155 & 0.214 \\
\hline 2 & 0.016 & 0.038 & 0.008 & 0.021 & 0.263 & 0.474 \\
\hline 3 & 0.021 & 0.038 & 0.006 & 0.029 & 0.013 & 0.088 \\
\hline 4 & 0.026 & 0.024 & 0.007 & 0.032 & 0.203 & 0.062 \\
\hline 5 & 0.019 & 0.041 & 0.011 & 0.024 & & \\
\hline
\end{tabular}

*) $1=$ lowest $\mathrm{P} / \mathrm{E}$ portfolio

$3=$ highest $\mathrm{P} / \mathrm{E}$ portfolio including the negative earning stocks

$4=$ highest $\mathrm{P} / \mathrm{E}$ portfolio excluding the negative earning stocks, and

$5=$ market portfolio.

and from 1998 to 2000 for period II. The results of the procedure are the three years of average monthly returns data for each portfolio that appear in the return columns of Table 2.

Besides analyzing the monthly returns of each portfolio, in relation to their $\mathrm{P} / \mathrm{E}$ ratios, there is an intention to explore the association between return and total risk (measured by $\sigma$ ) as well as the association between portfolio return and its systematic risk (measured by $\beta$ ).

Portfolio betas are calculated by estimating four equations using ordinary least squares (OLS), where we regress the monthly portfolio return against the monthly market return (Equation 3).

$$
\mathrm{R}_{\mathrm{Pi}, \mathrm{t}}=\alpha_{\mathrm{P}}+\beta_{\mathrm{P}} \mathrm{R}_{\mathrm{Mi}, \mathrm{t}}
$$

where

$\mathrm{R}_{\mathrm{P}, \mathrm{t}}=$ Return of $i^{\text {th }}$ portfolio at time $t$ $(\mathrm{i}=1,2, \ldots, 4)$

$\mathrm{R}_{\mathrm{Mi}, \mathrm{t}}=$ Market return at time $t$
All of above figures —rates of returns, standard deviation, and beta of each portfolio- are then used as the basis for evaluating the portfolio performance.

\section{Empirical Results}

\section{Market Performance Analysis}

Fluctuation of $\mathrm{P} / \mathrm{E}$ ratios in Jakarta Stock Exchange can be studied from Figure 1 . The figure clearly shows that in general, $\mathrm{P} / \mathrm{E}$ ratios were relatively higher in the beginning of 1990s, as compared to the ending part of the decade. At the beginning of 1991 market $\mathrm{P} / \mathrm{E}$ ratio was about 30 , which is considered relatively high by analysts. In the middle of 1996, for instance, the market $\mathrm{P} / \mathrm{E}$ figure dropped to 22.5 and at the end of decade it became 6.1.

The $\mathrm{P} / \mathrm{E}$ ratios' down sloping trend is logically explained by taking into account the interrelationship between capital market activities and the worsening of the country's economy and business condi- 
tions. It is widely understood that regional economic turbulence, started in 1997 , brings serious effects to Indonesian economy. Combined with country's political unrest, country's business risk becomes higher and investment opportunities tend to slow down. Business environment became unfavorable and, if not all, many businesses' profitability became lower in general. In turn, stock prices dropped even more significantly, which is indicated by some tremendous decreases in market composite index. By the end of 1998 market index (Indeks Harga Saham Gabungan or IHSG) became less than 400 as compared to around 600 in 1993.

The question of whether low $\mathrm{P} / \mathrm{E}$ effect can be detected in Indonesian capital market as a whole can be answered primarily by studying the information provided by Table 1 , which consists of market average $\mathrm{P} / \mathrm{E}$ ratio and average market return for three months following the P/E. During the period of 1991 , the P/E decreases from 21.90 to $21.85,19.13$, and finally to become 15.48 by the end of the year. However, the average returns for three months following the $\mathrm{P} / \mathrm{E}$ do not show any particular pattern or direction.

Similar explanations can be given by other years during the observation period. During the year of 2000, for example, the $\mathrm{P} / \mathrm{E}$ ratios form a decreasing pattern from 13.68 to $14.38,6.08$, and 5.11. If the low P/ $\mathrm{E}$ effect is there, then the market return should have shown an increasing pattern during the same period of time. However, what we find instead, is a relatively randomized pattern of market return. Thus, the table technically shows that low P/E effect does not exist in Indonesian market. More specifically, a consistent pattern of relationship between $\mathrm{P} / \mathrm{E}$ and return cannot be observed.
In the presence of low P/E effect, the dots in Figure 2 should form a downsloping pattern of distribution. In other words, they are somehow concentrated in three extreme locations:

(1) The dots are concentrated in upperleft side of the graph if $\mathrm{P} / \mathrm{E}$ ratios are low,

(2) The dots are concentrated in mediumcenter of the graph if $\mathrm{P} / \mathrm{E}$ ratios are in medium size, and

(3) If the $\mathrm{P} / \mathrm{E}$ ratios are high then the dots are concentrated in the lower right of the graph.

The actual distribution pattern presented in Figure 2 is far from showing the presence of low $\mathrm{P} / \mathrm{E}$ effect since the dots are scattered almost randomly through out the graph.

To strengthen our descriptive analysis, a simple regression procedure between average market return (lag) and market P/ E ratio using ordinary least square estimation provides the following results:

$$
\begin{array}{lll}
\text { LAGRET }= & 0.038- & 0.274 \text { MPER } \\
\text { t-stat } & (1.642) & (-1.732)
\end{array}
$$

where:

LAGRET $=$ Average monthly market return three months following $\mathrm{P} / \mathrm{E}$

MPER = Market $\mathrm{P} / \mathrm{E}$ ratio

Actually, the negative regression coefficient is a "correct" sign for confirming the presence of low P/E effect in the market. The sign indicates that market return for three months following $\mathrm{P} / \mathrm{E}$ decreases as $\mathrm{P} / \mathrm{E}$ increases, or it increases as $\mathrm{P} / \mathrm{E}$ decreases. However, the low value of $\mathrm{t}-$ statistics does not support the robustness of this negative relationship. So, from the 
statistical point of view, we underline the fact that the low P/E effect is "not really there".

\section{Portfolio Performance Analysis}

As mentioned in the previous section, a more micro-portfolio analysis is undertaken in order to examine the presence of low P/E effect in a more detail form. In macro level, we have analyzed the market for the whole ten-year period. In this section, we intend to have a more focused attention to the six-year periods surrounding the "turning year" of 1997 and divide the period of analysis into two sub-periods; 1994-1996 and 1998-2000.

Examinations of the scores provided by Table 2 bring us to several conclusions regarding the matter in the selected portfolios in each period. The table consists of average returns gained by each portfolio that we have constructed and ranked from low to high P/E. Portfolio 1 is the lowest P/ E portfolio and portfolio 5 is the market portfolio. Table 2 also prepares the values of portfolios' total risks (measured by s) and systematic risks (measured by b), so, following Basu (1977) and Johnson et al. (1989), we can examine again the association between return and risk for each portfolio.

When we focus our attention to pe$\operatorname{riod} \mathrm{I}$, the pre-crisis period, it is quite apparent that the pattern supporting the low $\mathrm{P} / \mathrm{E}$ portfolio hypothesis is not observed. Portfolio 1, the lowest P/E portfolio, provides monthly average return of 1.6 percent, which is not higher than those of other portfolios. In fact, this rate is less than the rates one would earn from the market (portfolio 5). Portfolio 2, which has a higher P/E than that of portfolio 1, instead of having lower return, only provides similar rates of return (1.6 percent). On the other hand, returns performed by portfolio 3 and 4 (which have higher P/E ratios, respectively) are significantly higher, which are also contradictory to the low $\mathrm{P} / \mathrm{E}$ effect hypothesis.

In the second period, actually the existence of low P/E effect is "almost" observed. The first portfolio provides the highest return (6.4 percent) than the other portfolio returns. In turn, portfolio 4 provides the lowest return, which is only 2.4 percent. The performances of those two portfolios per se seem to support the hypothesis. However, instead of performing lower return, portfolio 3 performs a similar return to portfolio 2 , namely 3.8 percent. Therefore, again, we cannot confirm presence of the low P/E effect for this period.

Further, lower return portfolios are not always associated with lower level of total risk (s) and systematic risk (b). In period I, more specifically, portfolio 2 (lowest return portfolio) has the largest standard deviation and beta of 0.008 and 0.263 , respectively. By contrast, the highest return portfolio 4 does not possess a highest standard deviation and beta. In the second period, the highest return portfolio 1 (6.4 percent) is not accompanied by the largest standard deviation and beta $(0.021$ and 0.214 , respectively) and the lowest return portfolio (portfolio 4) does not have the smallest standard deviation, even though it possesses the lowest beta. These results contradict with those reported by Basu and seem to be parallel to the findings of Johnson et al. (1989).

\section{Conclusion}

The study examines the behavior of the Indonesian stock market returns with respect to the $\mathrm{P} / \mathrm{E}$ ratios by concentrating on the question of whether the low P/E effect exists in the market. In one side, the 
Asri-Re-examiningtheExistence ofLowPrice-EarningsRatioEffects

topic remains relevant due to the fact that until nowadays, $\mathrm{P} / \mathrm{E}$ ratio is still one of popular aspects considered by market players, no matter whether they follow technical or fundamental analysis. On the other side, the hypothesis of low $\mathrm{P} / \mathrm{E}$ effect is still facing some ambiguities.

After conducting a two-level of analysis, macro and micro levels, we can conclude that the low $\mathrm{P} / \mathrm{E}$ effect does not exist in Indonesian market. Using partially similar research procedures to that of Johnson et al. (1989), the study provides some results that confirming their findings even though the procedures are applied in a completely different type of market. Finally, the study does not detect any structural change in market return behavior towards the $\mathrm{P} / \mathrm{E}$ ratio from "pre-crisis period" to "crisis period."

\section{Reference}

Alford, A. W. 1992. The effect of the set of comparable firms on the accuracy of the priceearnings valuation method. Journal of Accounting Research (Spring): 94-108.

Ball, R. 1978. Anomalies in relationship between securities' yields and yield-surrogates. Journal of Financial Economics (June/September): 103-126.

Banz, R. W. 1981. The relationship between return and market value of common stocks. Journal of Financial Economics 9 (March): 3-18.

Basu, S. 1977. Investment performance of common stocks in relation to their priceearnings ratios: A test of the efficient market hypothesis. Journal of Finance 32 (June): 663-682.

Boastman, J. R., and E. F. Baskin. 1981. Asset valuation with incomplete market. The Accounting Review (January): 38-53.

Brown, P., A. W. Kleidon, and T. A. Marsh. 1983. New evidence on the nature of sizerelated anomalies in stock prices. Journal of Financial Economics 12 (June): 33-56.

Cragg, J. G., and B. G. Malkiel. 1982. Expectation and the Structure of Share Prices. Chicago: University of Chicago Press.

Francis, J. C. 1986. Investments: Analysis and Management. $4^{\text {th. }}$ Ed. New York: McGrawHill.

Graham, B., D. L. Dodd, and S. Cottle. 1962. Security Analysis: Principles and Techniques. New York: McGraww Hill.

Jaffee, J., D. B. Keim, and R. Westerfield. 1989. Earnings yields, market values, and stock returns. Journal of Finance (March): 135-148.

Johnson, R. S., L. C. Fiore, and R. Zuber. 1989. The investment performance of common stocks in relation to their price-earnings ratios: An update of Basu study. The Financial Review 24 (3) (August): 499-505.

Jones, R. C. 1987. Stock Selection: Portfolio Strategy. New York: Goldman Sachs. 
Keim, D. 1983. Size related anomalies and stock return seasonality: Further empirical evidence. 1983. Journal of Financial Economics 12 (June): 13-32.

Klein, A., and J. Rosenfeld. 1991. PE ratios, earnings expectations, and abnormal return. The Journal of Financial Research XIV (1) (Spring).

Litzenberger, R. H., and C. U. Rao. 1971. Estimate of Marginal Rate of Time Preference and Average Risk Aversion of Investors in Electric Utility Shares: 1960-1961. Bell Journal of Economics and Management Science (Spring): 265-277.

Radcliffe, R. C. 1987. Investments: Concepts, Analysis, and Strategy. $2^{\text {nd }}$ Ed. Glen view; Scott, Foresman.

Reinagum, M. R. 1983. The anomalous stock market behavior of small firms in January: Empirical tests for tax-loss selling effects. Journal of Financial Economics 12 (June): 89-104.

Roll, R. 1981. A possible explanation of the small firm effect. Journal of Finance 36 (September): 879-888.

Shen, P. 2000. The P/E ratio and stock market performance. Federal Reserve Bank of Kansas City Economic Review (4 ${ }^{\text {th }}$ Quarter): 23-36. 